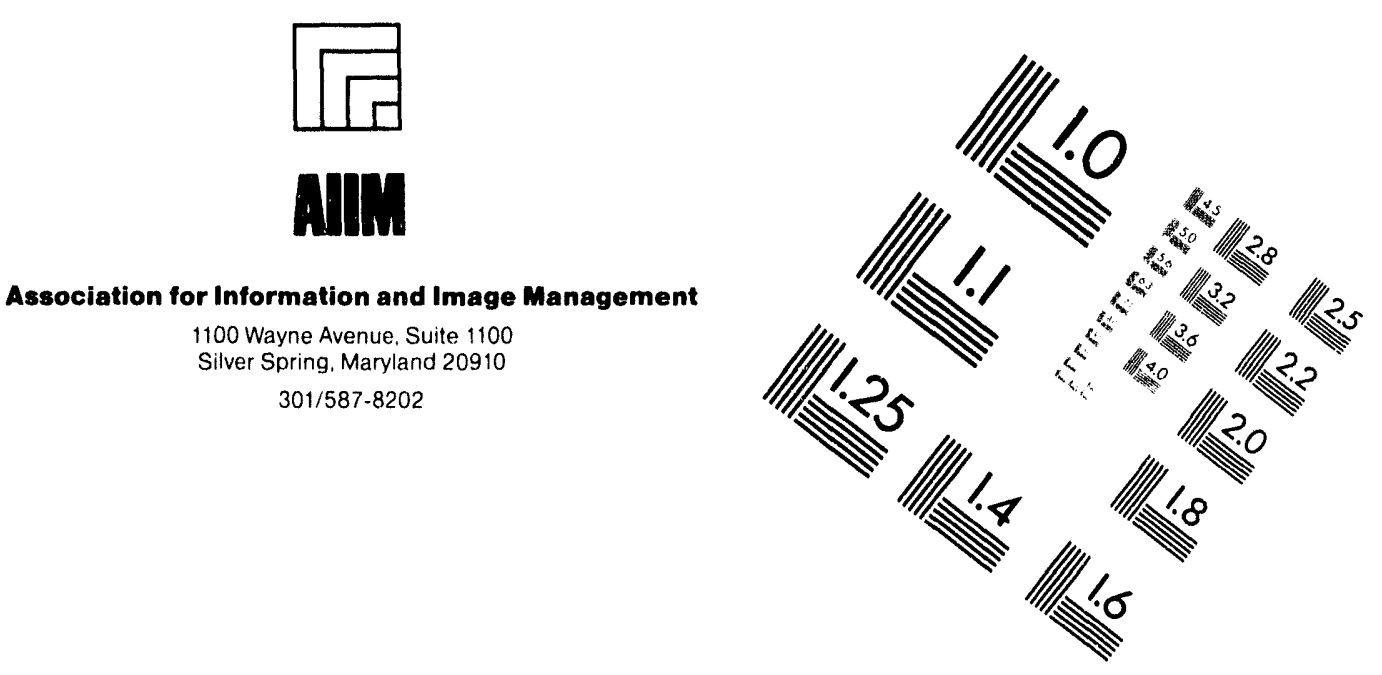

\title{
Centimeter
}

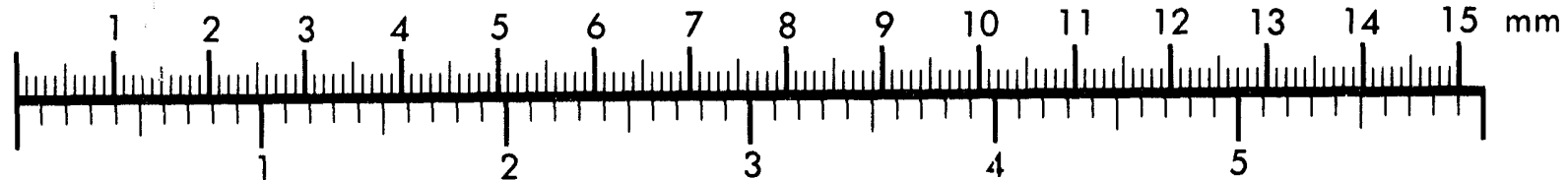

Inches
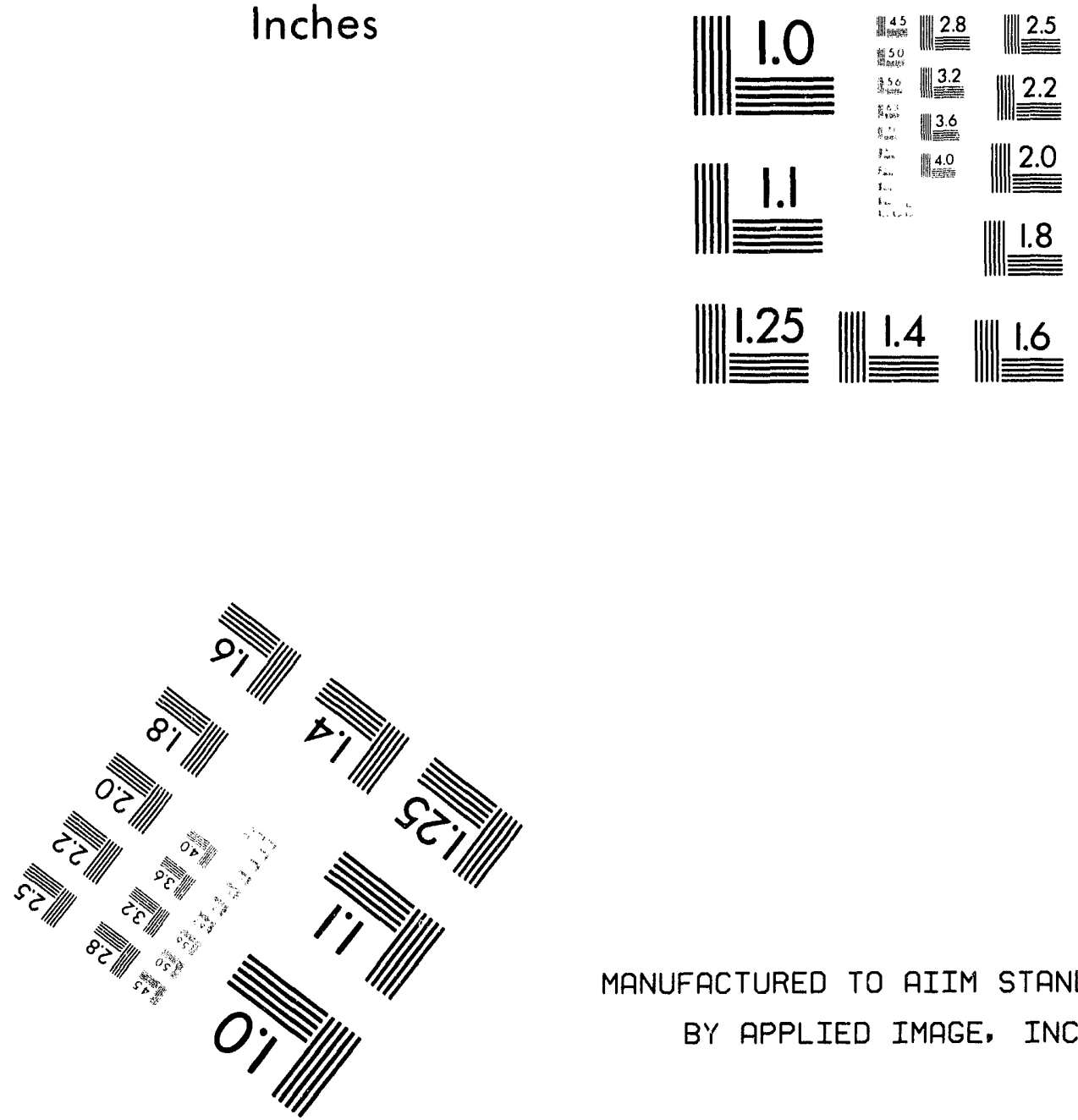

MANUFACTURED TO AIIM STANDARDS

BY APPLIED IMAGE, INC.

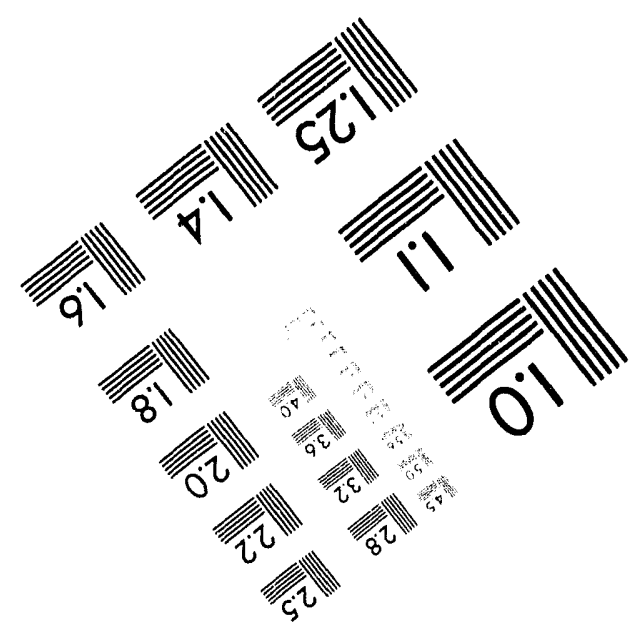



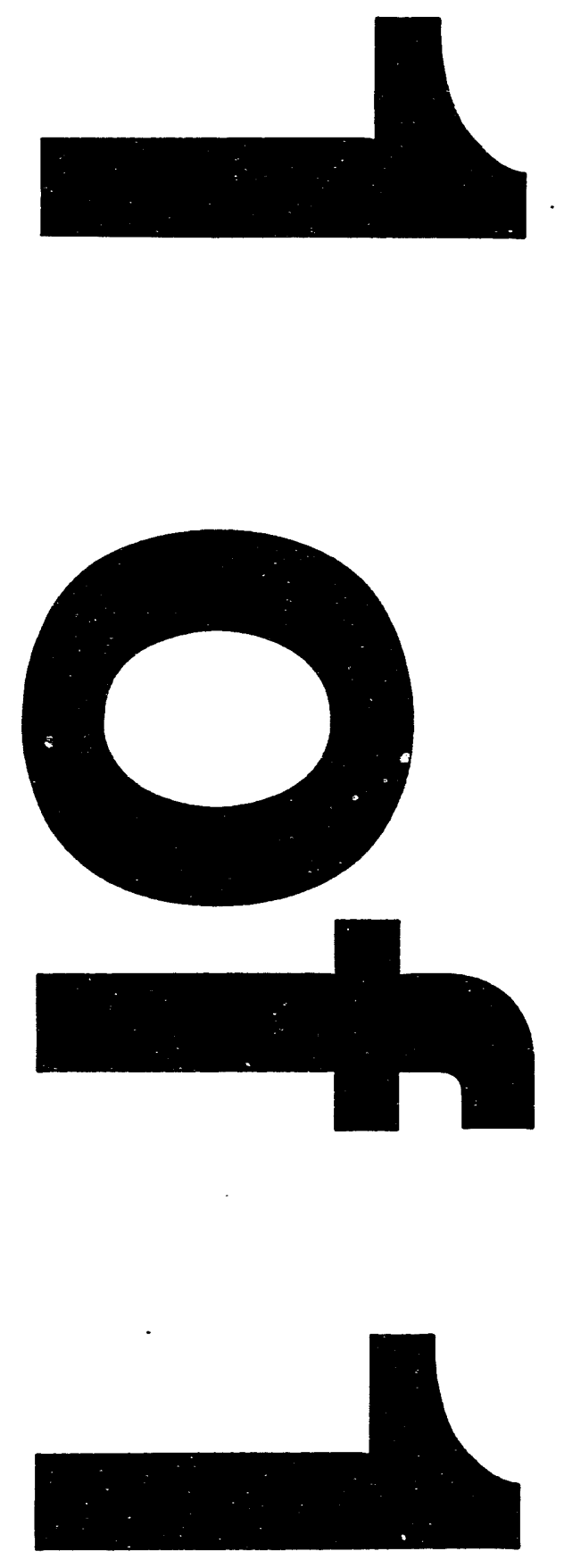


\section{Innovative In Situ Treatment Approach Selected for the Department of Energy Savannah River Site Sanitary Landfill (U)*}

by
A. Suer
Westinghouse Savannah River Company
Environmental Restoration Department
Aiken, SC 29801

J. Knapp

CDM Federal Programs Corporation

Fairfax, VA 22033

\section{RECEIVED \\ FEB 181994 \\ OSTI}

\section{Abstract}

Pursuant to a settlement agreement reached between the U.S. Department of Energy (DOE) and the South Carolina Department of Health and Environmental Control (SCDHEC), the Sanitary Landfill at the Savannah River Site (SRS) will be closed. This paper addresses the approach used to select the innovative in situ treatment alternative for the groundwater and the vadose zone associated with the landfill.

* The information in this article was developed during the course of work under Contract No. DEAC099-88SR18035 with the U.S. Department of Energy. 


\section{DISCLAIMER}

This report was prepared as an account of work sponsored by an agency of the United States Government. Neither the United States Government nor any agency thereof, nor any of their employees, makes any warranty, express or implied, or assumes any legal liability or responsibility for the accuracy, completeness, or usefulness of any information, apparatus, product, or process disclosed, or represents that its use would not infringe privately owned rights. Reference herein to any specific commercial product, process, or service by trade name, trademark, manufacturer, or otherwise does not necessarily constitute or imply its endorsement, recommendation, or favoring by the United States Government or any agency thereof. The views and opinions of authors expressed herein do not necessarily state or reflect those of the United States Government or sny agency thereof.

This report has been reproduced directly from the best available copy.

Available to DOE and DOE contractors from the Office of Scientific and Technical Information, P. O. Box 62. Oak Ridge. TN 37831; prices available from (615) $576-8401$.

Available to the public from the National Technical Information Service, U. S. Department of Commerce, 5285 Port Royal Rd., Springfield, VA 22161 


\section{Introduction}

SRS is owned and operated by DOE and has been managed by the Westinghouse Savannah River Company (WSRC) since April 1989. Historically, the Site's mission had been to produce nuclear materials for national defense. SRS is a 310-square-mile facility located in a rural area of South Carolina along the Savannah River, principally in Aiken and Barnwell counties. SRS is approximately 25 miles southeast of Augusta, Georgia, and 20 miles south of Aiken. There are about 363,253 residents in the counties surrounding SRS (Allendale, Aiken, and Barnwell counties in South Carolina and Burke and Richmond counties in Georgia). ${ }^{1}$

The SRS Sanitary Landfill is an approximate 70-acre site. In 1974, it was a 32-acre site receiving solid waste from a variety of sources, including Site construction areas, offices, shops, and the cafeteria. In 1987, the original area reached its capacity and a 16-acre northern expansion and a 22-acre southern expansion were added. The southern expansion is nearing capacity, and the northern expansion opened in 1993.

During its operation, the Sanitary Landfill received rags and wipes used with Resource Conservation and Recovery Act (RCRA) F-listed solvents. In 1988, the Sanitary Landfill became the subject of a RCRA facility investigation and was designated a RCRA solid waste management unit because of recurring evidence of RCRA hazardous constituents in the groundwater. In December 1989, SRS was added to the National Priority List. At the time, the Sanitary Landfill was included in a combined RCRAVComprehensive Environmental Response, Compensation and Liability Act (CERCLA) unit list in the Federal Facility Agreement. As a result of an ongoing RCRA permit investigation, the U.S. Environmental Protection Agency (EPA) removed the Sanitary Landfill from the combined RCRA/CERCLA unit list on August 29, 1991.

DOE and SCDHEC reached a settlement agreement (SW-91-51) in August 1991, outlining the steps DOE would take to comply with RCRA regulations. Principally, DOE would close the portions of the landfill containing the solvent rags to comply with Subpart G (closure and postclosure) of Part 265 (Interim Status Standards for Owners and Operators of Hazardous Waste Treatment Storage and Disposal Facilities) of the South Carolina Hazardous Waste Management Regulations (SCHWMR).

The settlement agreement also states that DOE submitted a Postclosure Part B Permit Application on March 31, 1993, for the portions of the landfill that received the solvent rags. The postclosure Part B permit application contained an alternate concentration limit (ACL) demonstration. If, based on the status reports or the final submission of the ACL, SCDHEC or DOE determines that an ACL is not appropriate, DOE must submit a corrective action plan (CAP) on or before March 31, 1994.

This paper describes the technology selection process conducted for the SRS Sanitary Landfill site and the innovative in situ treatment alternative selected for the groundwater and the vadose zone associated with the landfill.

\section{Nature and Extent of Contamination}

The contaminants of concern associated with the SRS Sanitary Landfill site include 13 RCRA organic and two RCRA inorganic constituents and tritium. The maximum detected concentrations of these contaminants in soil and groundwater, the associated maximum contaminant level, toxicity characteristic leaching procedures, and proposed alternate ACL values for each constituent are presented in Table 1 . 
Table 1. Contaminants of Concern

\begin{tabular}{|c|c|c|c|c|c|}
\hline $\begin{array}{r}\text { Constlituents } \\
\end{array}$ & $\begin{array}{c}\text { Soll Maximum } \\
\text { Concentration } \\
\text { (ug/kg) }\end{array}$ & $\begin{array}{l}\text { Groundwater } \\
\text { Maximum } \\
\text { Concentration } \\
\text { (ug/kg) }\end{array}$ & $\begin{array}{c}M C L^{b} \\
(u g / k g)\end{array}$ & $\begin{array}{c}\text { TCLPd } \\
(\mathrm{ug} / \mathbf{k g})\end{array}$ & $\begin{array}{c}A C L^{\circ} \\
(u g / k g)\end{array}$ \\
\hline \multicolumn{6}{|c|}{ RCRA Organic Constituents } \\
\hline 1,1,1-Trichloroethane & 75 & 249 & 200 & NR & 249 \\
\hline trans 1,2-Dichcloroethene & not detected & 754 & 100 & NR & 560 \\
\hline Vinyl Chloride & not cietected & 400 & 2 & 200 & 2 \\
\hline Dichlorodifluoromethane & not analyzed & 94 & $\mathrm{NR}^{\mathrm{c}}$ & NR & 94 \\
\hline Tetrachloroethylene & 87 & 2028 & 5 & 700 & 2,208 \\
\hline Trichloroethylene & 20 & 97 & 5 & 500 & 28.5 \\
\hline Trichclorofluoromethane & not analyzed & $62 \overline{25}$ & NR & $\overline{N A}$ & 625 \\
\hline $\begin{array}{l}\text { Dichloromethance (Methylene } \\
\text { Chloride }\end{array}$ & not detected & 757 & NR & NR & 757 \\
\hline 1,4-Dichlorobenzene & not analyzed & 99 & 75 & 7,500 & $\overline{99}$ \\
\hline Chlorobenzene & not detected & 83.9 & 100 & 100,000 & No ACL \\
\hline Benzene & not detected & 21.2 & $\overline{5}$ & 500 & 21.2 \\
\hline Ethylbenzene & 70 & 230 & 700 & NA & No ACL \\
\hline Xylenes & 240 & 248 & 10,000 & $\overline{\mathrm{NR}}$ & No ACL \\
\hline \multicolumn{6}{|c|}{ RCRA Inorganic Constifuents } \\
\hline Arsenic & not detected & 50 & 50 & 5,000 & No ACL \\
\hline \multirow[t]{2}{*}{ Lead } & 6,930 & 91 & 15 & 5,000 & 34 \\
\hline & $\begin{array}{c}\text { Soli Maximum } \\
\text { Concentration } \\
\text { (ug/kg) }\end{array}$ & $\begin{array}{l}\text { Groundwater } \\
\text { Maximum } \\
\text { Concentration } \\
\text { (ug/kg) }\end{array}$ & \multicolumn{3}{|c|}{$\underset{(u g / k g)}{M C L^{b}}$} \\
\hline \multicolumn{6}{|l|}{ NonRCAA Constituents } \\
\hline Tritium & unavailabiel & 101,000 & 20,000 & & 92,000 \\
\hline
\end{tabular}

Notes:

a 40 CFR 261, Appendix VIII or 40 CFR 264, Appendix Constituent

bMaximum contaminant level (MCL)

CValue was not reported (NA)

$\mathrm{d}_{\text {Toxicity characteristic leaching procedure (TCLP) }}$

eAlternate concentration limit (ACL)

'Mixing zone (MZ)

Source: 1992 RCRA Part B Permit Renewal Application (WSRC 1993a) 
Based upon available information, the following conclusions may be drawn regarding the nature and extent of groundwater contamination at the SRS Sanitary Landfill:2

- The landfill will continue to be a source of contaminants until some type of source control is implemented.

- The landfill extends to within 0 to 10 feet from the water table, depending on seasonal variations.

- Contaminated groundwater contains low levels of organics, predominantly chlorinated aliphatic compounds, benzene, toluene, ethylbenzene, and xylene (BTEX). Low levels of radionuclides (primarily tritium) have also been detected.

- The total organic halide values were used to identify the contaminated plume.

- Groundwater contamination is isolated to the Steed Pond Aquifer, based upon the assumption that the Crouch Branch Confining Unit is an effective confining unit. In addition, the flow path is close to the discharge area of Upper Three Runs. It is assumed that only the upper Steed Pond Aquifer (approximately 50 feet below the water table) will need to be remediated.

- The plume dimensions have not been refined; however, for the purposes of this report, it is assumed that the plume covers an area of $10^{6}$ square feet ( 1000 feet by 1000 feet) and extends to a depth of 50 feet.

- To evaluate pump and treat methods, the extraction rate would not be a limiting factor. Extraction systems can be designed to extract at rates up to 150 gallons to 200 gallons per minute (gpm).

- The amount of contaminated groundwater is estimated to be about 250 million gallons, based on plume dimensions of 1000 feet $\times 1000$ feet $\times 50$ feet and a porosity of 0.30 .

- The contaminant plume is moving from the landfill toward Upper Three Runs (south).

Limited data are available regarding the extent of migration in the vadose zone. For the purposes of technology selection, the vadose zone has been divided into two areas: soil beneath the landfill and soil overlying the contaminated groundwater plume. Based upon available information, the following conclusions may be drawn regarding the extent of vadose zone contamination at the SRS Sanitary Landfill. ${ }^{2}$

- The COCs for the vadose zone are the same as the COCs for the groundwater because the contaminants detected in the groundwater must first pass through the vadose zone beneath the landfill.

- Contaminated soil contains above background levels of volatile organics (predominantly chlorinated aliphatic compounds and BTEX), lead, arsenic, and tritium based upon soil and groundwater sampling data.

- The thickness of the vadose zone varies and does not include the Sanitary Landfill trenches.

- There are two contaminated soil areas associated with the Sanitary Landfill. The assumptions developed for these two areas are described in Table 2: 
Table 2. Soil descriptions

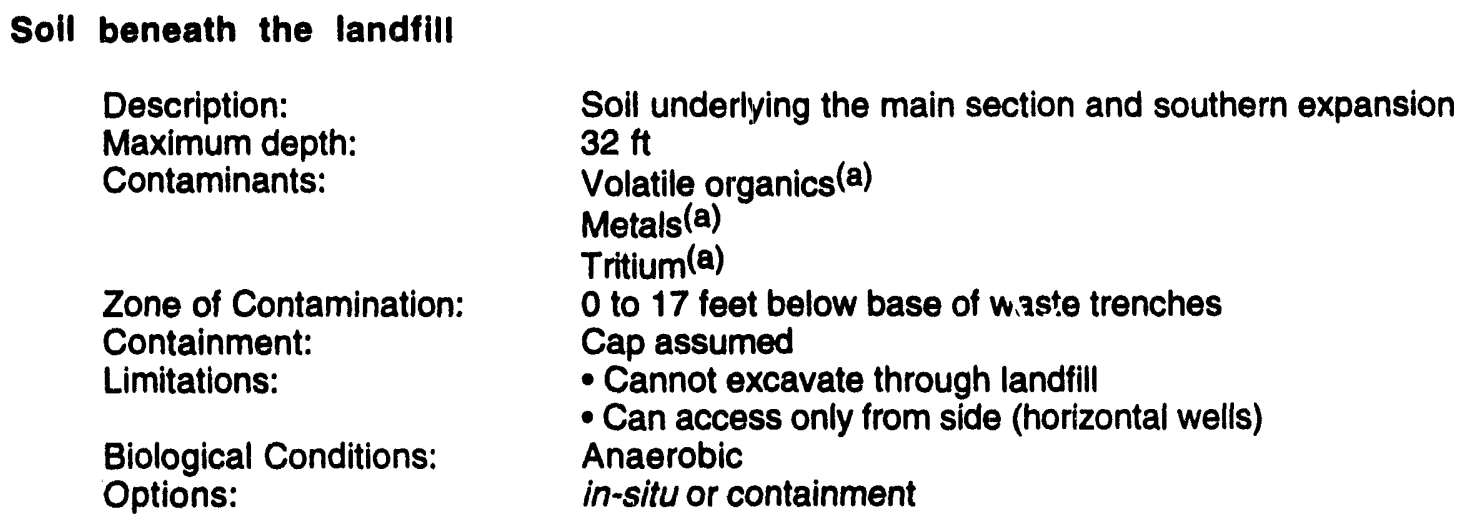

Description: Maximum depth: Contaminants:

Zone of Contamination: Containment: Limitations:

Biological Conditions: Options:

Soil underlying the main section and southern expansion $32 \mathrm{ft}$

Volatile organics(a)

Metals(a)

Tritium(a)

0 to 17 feet below base of w.aste trenches

Cap assumed

- Cannot excavate through landfill

- Can access only from side (horizontal wells)

Anaerobic

in-situ or containment

Soll above the groundwater plume (between Sanitary Landfill and Upper Three Runs)

Description: Maximum Depth: Contaminants:

Zone of contamination Containment: Limitations: Biological Conditions: Options:
Soil overlying the containment groundwater plume $26 \mathrm{ft}$

Volatile organics(b)

Metals(b)

Tritium(b)

8 to 26 feet below land surface (c) no cap Assumed no limitations

Varying to aerobic

in situ, ex-situ, or containment

(a) Maximum concentrations based on soil data. Maximum concentrations based on groundwater data were used in the absence of soil data.

(b) Maximum concentrations based on groundwater data.

(c) The soil above the groundwater plume has not been adequately studied to determine the nature and extent of contamination. This contamination is presumed based on the existence of groundwater contarnination beneath it. The groundwater may allow volatile organics to vaporize and enter the vadose zone, and the fluctuating groundwater table may deposit contaminants into the vadose zone. With either scenario, the presumed existence of contamination does not warrant excavation because of uncertainty of the boundaries of contamination and the minimal health risk posed. However, because contamination dons exist in the groundwater, which will be remediated, the presumed contamination in the vadose zone can be remediated with the known contamination in the groundwater, using an in situ system that addresses bothmedia.

\section{Technology Selection Process}

Technology selection for the SRS Sanitary Landfill was conducted using the methodology in the EPA's guidance document, Guidance for Conducting Remedial Investigations and Feasibility Studies (RI/FS) Under CERCLA. ${ }^{3}$ To ensure a systematic and thorough analysis and to meet a compressed regulatory deadline, some steps in the RI/FS guidance occurred earlier than normal. For example, after the initial screening of technology types and process options for implementability, the media- or contaminant-specific process options for groundwater remediation were evaluated against seven RI/FS threshold and balancing criteria prescribed in the RI/FS guidance. 
For the SRS Sanitary Landfill, identifying and screening technologies and process options consisted of the following steps:

1. identification of general response actions

2 . identification of technology types and process options

3. initial screening of technology types and process options based on technical implementability

4. detailed screening of process options

The initial screening eliminated technology types and process options from further consideration based on technical implementability. The final screening evaluated the remaining technology types and process options against the seven threshold and balancing criteria. This approach incorporates a more comprehensive evaluation at the beginning of the remedial alternative selection process. Compressing evaluation process will allow later stages to proceed more rapidly to meet the overall settlement agreement schedule. Additional information on the technology selection process follows.

\section{Initial Screening of Process Options}

Initial screening was performed by considering contaminant types, concentrations, and site conditions specific to the SRS Sanitary Landfill Site and evaluating the technical implementability of each process option to those contaminants and site conditions. Each process option wass qualified as one of the following:

- Potentially viable - The process option is technically implementable at the site and is retained for further consideration.

- Not viable - The process option is technically implementable, but is impractical under existing site conditions or will not be as cost-effective as other options. This process option is eliminated from further consideration.

- Not applicable - The process option is not technically implementable at the site and is eliminated from further consideration.

For the groundwater, 112 process options were initially screened for technical implementability. Of these, 54 were retained for a more detailed evaluation. For the vadose zone, 83 process options were initially screened, and 28 were retained for detailed screening. ${ }^{2}$

\section{Detailed Screening of Process Options}

In the detailed screening step, the process options determined to be technically implementable in the initial screening step were evaluated in greater detail, using the following seven RI/FS criteria: ${ }^{3}$

- Threshold criteria

- overall protection of human health and the environment

- compliance with applicable or relevant and appropriate requirements (ARARS)

- Balancing criteria

- long-term effectiveness

- reduction of toxicity, mobility, or volume

- short-term effectiveness

- implementability

- cost 
For the groundwater, 26 were selected in the detailed screening. Process options passing this second screen were combined into eight remedial alternatives, which were further evaluated. ${ }^{2}$ The eight groundwater alternatives follow: ${ }^{4}$

- no action (required to be evaluated by EPA guidance)

- limited action, including deed restrictions and groundwater monitoring

- containment (which assumes a multimedia cap over the surface unit) including cryogenic soil freezing and extraction and treatment of a limited amount of groundwater to prevent groundwater mounding in the area enclosed by cryogenic cell

- in situ permeable bed treatment with offsite regeneration of the bed medium

- in situ biological treatment supplemented by in situ air stripping/air sparging and granulated activated carbon treatment of the vapor phase

- extraction and ex situ treatment (pump and treat) with coagulation/flocculation and precipitation of inorganics, followed by air stripping of organics using either phased GAC adsorption or catalytic oxidation of offgases from the air stripper

- extraction with freeze crystallization and onsite incineration of concentrated waste

- extraction with reverse osmosis and ultrafiltration

In situ treatment technologies are strong contenders for the selected remedial alternative because they leave the water in the ground. In situ treatment does not bring tritiated water to the surface and eliminates the problem of disposing of or reinjecting tritiated groundwater. In addition, Alternative 5, which includes in situ biological treatment and in situ air stripping/air sparging focuses on the organic contaminants that are the greatest concern at the SRS Sanitary Landfill site. The low levels of metals that require minimal treatment are not inhibitory to the bioremediation treatment process unlike some of the ex situ technologies that require metals removal as a pretreatment step. Based on these attributes, in situ bioremediation with air stripping/air sparging was the selected groundwater remedial alternative.

For the vadose zone, 17 process options were selected in the detailed screening. These process options were combined into ten remedial alternatives (six for the contaminated soil beneath the landfill and four for the contaminated soil above the groundwater plume). The 10 vadose zone alternatives follow: 5

- Contaminated soil beneath the landfill

- Alternative 1A: no action

- Alternative 2B: limited action

- Alternative 3A: containment

- Alternative 4A: soil gas extraction/containment

- Alternative 5A: soil gas extraction

- Alternative 6A: soil gas extraction/biotreatment

- Contaminated soil above the groundwater plume

- Alternative 1B: no action

- Alternative 2B: limited action

- Alternative 3B: soil gas extraction

- Alternative 4B: soil gas extraction/biotreatment

Because of the uncertainty associated with the nature and extent of vadose zone contamination, a phased approach was selected as the most feasible, comprehensive solution; remediating the groundwater first and then the vadose zone, if required. If it is later determined that the vadose zone required remediation, the remedial alternative would include in situ bioremediation and soil gas extraction. 


\section{Selected Alternative}

The selected alternate will include: ${ }^{2}$

- capping the landfill

- monitoring the groundwater plume

- remediating groundwater, as necessary, using in situ bioremediation and in situ air stripping/air sparging, combined with soil gas extraction and soil gas treatment system (i.e., vapor-phase granular activated carbon)

- evaluating the addition of a horizontal well treatment and extraction system in the vadose zone beneath the landfill to control the source if the groundwater cleanup objectives are not met

- in situ bioremediating of the vadose zone beneath the landfill supplemented by soil gas extraction and treatment, if required

No treatment of the vadose zone above the groundwater plume is recommended at this time. If additional data indicate a source of contamination in this zone, additional treatment will be considered.

\section{References}

1. USDOC, U.S. Department of Commerce, Census Bureau, Census of Population and Housing Characteristics (CPH-1), Washington, D.C. (1990).

2. WSRC 1993b, Westinghouse Savannah River Company, Groundwater and Vadose Zone Combined Alternative Selection Report $(U)$, SRS, Westinghouse Savannah River Company, Aiken, SC, WSRC-RP-93-892 (1993).

3. EPA 1988, U.S. Environmental Protection Agency, 1988, Guidance for Conducting Remedial Investigations and Feasibility Studies Under CERCLA, U.S. Environmental Protection Agency, Washington, D.C., EPA/540/G-89/DOC.

4. WSRC 1993c, Westinghouse Savannah River Company, Groundwater Remediation Technology Selection Report (U) Sanitary Landfill (740-G) Savannah River Site, Westinghouse Savannah River Company, Aiken, SC WSRC-RP-93-301.

5. WSRC 1993d, Westinghouse Savannah River Company, Vadose Zone Remediation Technology Selection Report (U) Sanitary Landfill Savannah River Site, Westinghouse Savannah River Company, Aiken, SC WSRC-RP-93-553. 

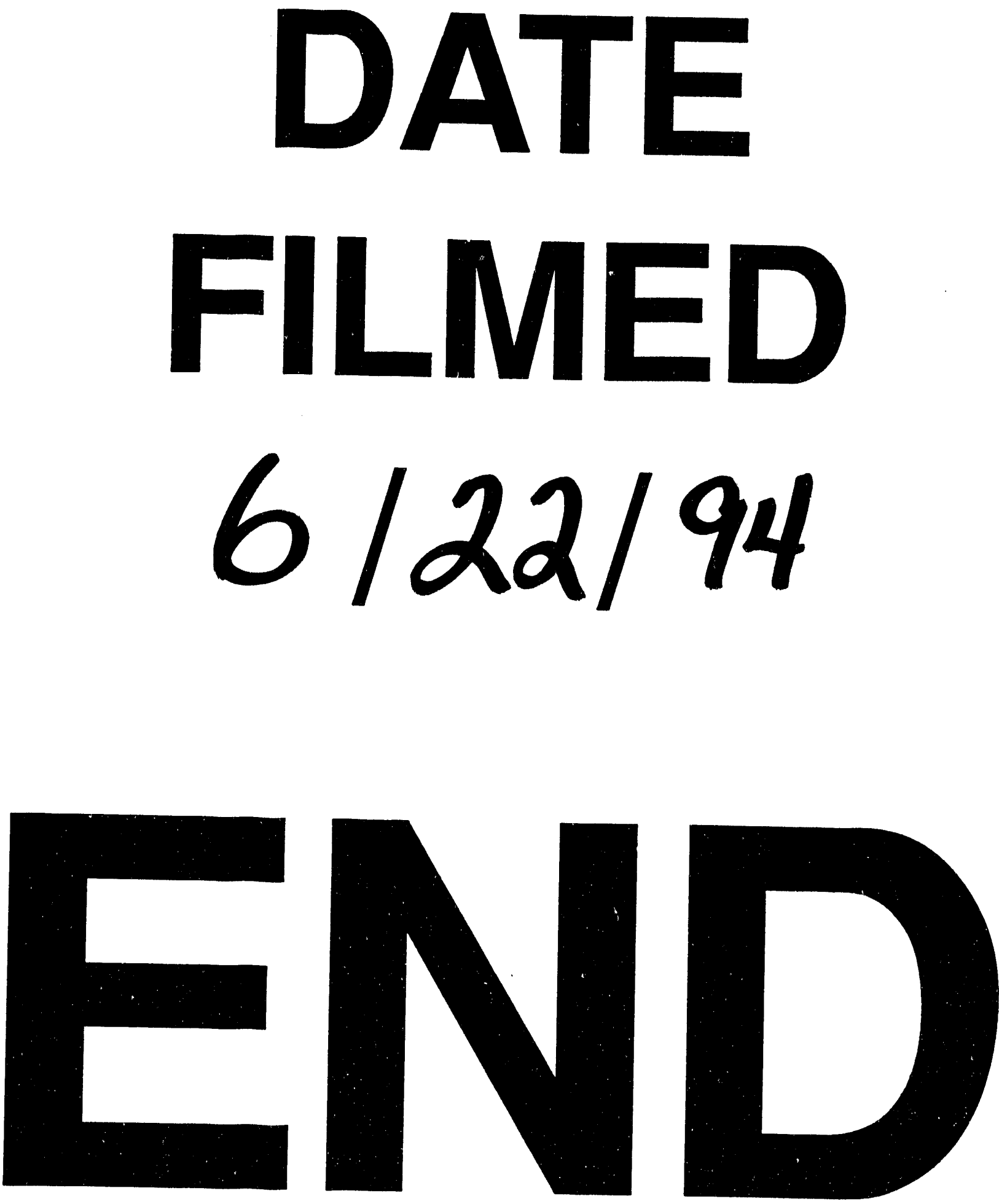
